\title{
Growth performance, carcass and meat quality of Karayaka female lambs born in different seasons
}

\author{
Ugur Sen', Mehmet Kuran' and Umran Ensoy² \\ ${ }^{1}$ Ondokuz Mayis University, Faculty of Agriculture, Samsun, Turkey, ${ }^{2}$ Gaziosmanpasa University, Faculty of Engineering \\ and Natural Sciences, Tokat, Turkey
}

\begin{abstract}
The aim of this study was to determine growth performance, carcass and meat quality of Karayaka female lambs born in different seasons. Winter born (breeding season; $n=15$ ) and autumn born (out of the breeding season; $n=15$ ) singleton female lambs were used in the study. Birth and slaughter weights of lambs in both groups were similar, but the weaning weight of the autumn born lambs was higher $(P<0.05)$. The autumn born lambs had lower carcass yield, lung, spleen and gastrocnemious muscle weights $(P<0.05)$, but higher liver, kidney, empty reticulo-rumen, empty small intestine, internal fat, suprarenal fat weights and a higher fat thickness over the longissimus dorsi muscle $(P<0.05)$. Additionally, the winter born lambs had higher cooking loss, drip loss and shear force values $(P<0.05)$, but lower dry matter and intramuscular fat $(P<0.05)$ in longissimus dorsi and semitendinosus muscles. There were significant differences between both groups in terms of meat colour characteristics $(P<0.05)$ except $b^{*}$ values for longissimus dorsi at $1 \mathrm{~h}$ and for semitendinosus at $24 \mathrm{~h}$. The results suggest that Karayaka female lambs born in winter and autumn seasons have different meat quality parameters and growth patterns at pre- and post-weaning.
\end{abstract}

Keywords: Karayaka lamb, lambing season, growth, meat quality, carcass characteristics

Abbreviations: ADG: average daily gain; GN: gastrocnemious; LD: longissimus dorsi; SM: semimembranosus; ST: semitendinosus 


\section{Introduction}

Karayaka sheep are well adapted to the severe conditions such as harsh climate and poor pasture that are the characteristics of the hills and uplands of the region and resistance to local diseases (Cam \& Kuran 2004a). Lambs of this breed are reared for meat production and have a high meat quality due to their mosaic dispersion pattern of fat among muscle fibres (Ulutas et al. 2010). Due to its adequate growth and fattening performance in harsh environment, the Karayaka sheep breed has been proposed to have a significant role in the genetic improvement programmes of native sheep breeds in Turkey (Sen et al. 2011).

It is believed that Karayaka sheep are seasonal breeders and in practice the annual breeding season begins in early autumn (september) and ends in early spring (february and march). However, Olfaz et al. (2010) reported that Karayaka ewes maintained on rangeland show a low seasonality for their estrus behaviour. They can exhibit a prolonged estrus pattern from the early autumn to the late spring, resulting in seasonal variations in birth dates of lambs throughout the year. It has been suggested that different lambing seasons play an important role in sheep production and have a significant influence on important economic features, such as birth weight, mortality rate, litter size and the offspring's daily gain (Susic et al. 2005, Yilmaz et al. 2007).

Generally the majority of the winter born Karayaka female lambs (the normal breeding season) are kept for breeding purposes by many producers, but culled female lambs and all lambs born out of the breeding season (non-winter born) are only used as fattening material. Previous studies on growth and carcass quality characteristics of Karayaka lambs and its crossbreeds used male lambs born in the normal breeding season (Olfaz et al. 2005, Yakan \& Unal 2010, Sen et al. 2011). Thus, there is no comparative information about growth and carcass quality characteristics of female lambs born in the normal lambing season and born out of the lambing season. In addition, environmental variations resulting from changes in the weather conditions, especially rainfall which directly affects herbage quantity and quality of the pasture, could affect growth performance, carcass and meat quality of lambs in different seasons (Unal et al. 2006). It is well accepted that various factors (Kuran et al. 1999, Cam et al. 2002, Cam \& Kuran 2004a, 2004b, Ocak et al. 2006) including nutritional conditions may influence the fetal growth resulting in altered post-natal performance (Munoz et al. 2009). Environmental differences between gestation seasons may therefore affect fetal growth during pregnancies in contracting seasons. Therefore, it is thought that the comparison of growth performance and meat quality of lambs born in the winter and autumn should provide useful information for practical purposes. Accordingly, the aim of this study was to determine growth performance, carcass and meat quality of Karayaka female lambs born in different seasons.

\section{Materials and methods}

The experimental procedures were approved by the Local Animal Care and Ethics Committee of Gaziosmanpasa University, Tokat, Turkey ensuring compliance with EC Directive 86/609/ EEC for animal experiments. The study was conducted at the experimental farm of the Gaziosmanpasa University, Tokat, Turkey $\left(40^{\circ} 31^{\prime} \mathrm{N}, 36^{\circ} 53^{\prime} \mathrm{E}\right.$ and $650 \mathrm{~m}$ above the sea level). 
The autumn born $(n=15)$ and winter born $(n=15)$ singleton female lambs were used in this study. All lambs were weighted within $12 \mathrm{~h}$ of birth, at 90 and 150 days of age. Following the lambing, all lambs were kept with their dams in the sheepfold for two weeks. Starting from day 15 of lambing, ewes were allowed to pasture in extensive areas of hills during the day time and to suckle their lambs over the nights in a house. After two weeks of age all lambs received the creep-feed concentrate and alfalfa hay during all day. The winter born lambs were housed until 150 days of age, while the autumn born lambs were permitted to pasture with their mother until weaning at day 90.

Management and feeding procedures for the winter and the autumn born lambs were quite similar during the post weaning period. In both seasons, lambs were weaned, weighted and shorn at 90 days of age. After weaning, all lambs in each group were housed together in $4 \times 6 \mathrm{~m}$ pens in a naturally ventilated animal house. Thus, they were fed as group with ad libitum concentrates and alfalfa hay until the 150 days of age. The chemical composition of experimental feeds is shown in Table 1. Water and mineral stone were freely available, and total feed consumption was recorded daily. Monthly averages of the outdoor temperature $\left({ }^{\circ} \mathrm{C}\right)$ and rain fall rate $\left(\mathrm{kg} / \mathrm{m}^{2}\right)$ data obtained from the Turkish State Metrological Service during the both experimental periods are presented in Figure 1.
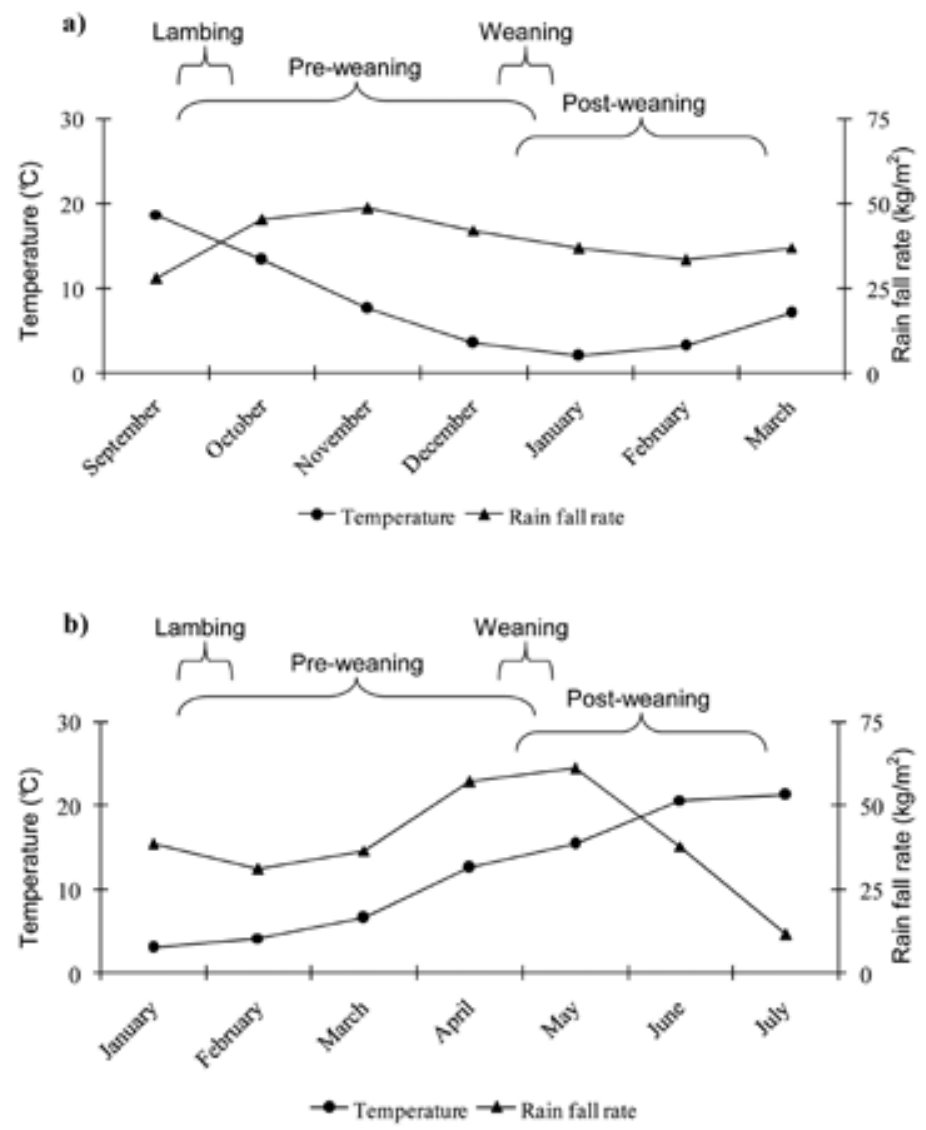

Figure 1

Monthly averages of outdoor temperature $\left({ }^{\circ} \mathrm{C}\right)$ and rain fall rate $\left(\mathrm{kg} / \mathrm{m}^{2}\right)$ during the experimental periods; a) for autumn born lambs, b) for winter born lambs. 
Table 1

Chemical composition of concentrates and alfalfa hay (\% on dry matter basis)

\begin{tabular}{lcc}
\hline Nutrients & Concentrate & Alfalfa hay \\
\hline Dry matter & 90.0 & 88.4 \\
Crude protein & 12.0 & 16.8 \\
Ether extract & 4.9 & 1.6 \\
Crude fibre & 12.0 & 24.1 \\
Ash & 9.0 & 9.6 \\
Metabolizable energy, kcal/kg DM & 2700 & 1951 \\
Minerals & & \\
$\quad$ Calcium & 0.9 & 1.8 \\
Phosphor & 0.5 & 0.4 \\
Sodium & 0.3 & 0.1 \\
Potassium & nd & 2.7 \\
Salt & 1.0 & nd \\
Vitamins, IU/kg & & \\
A & 7000 & nd \\
D & 700 & nd \\
E & 25 & nd \\
\hline
\end{tabular}

nd: not determined

All lambs were weighted and transported to an abattoir at 150 days of age. All lambs were slaughtered by the standard commercial slaughter procedure. Warm carcass weights of lambs in both groups were measured after removing all internal organs. The internal organs (spleen, lungs, liver and kidney), empty reticulo-rumen and empty intestine were weighted. In addition weights of the internal, pelvic, kidney fat tissues and semitendinosus (ST), semimembranosus (SM), gastrocnemious (GN) muscles from the left side of the carcasses were recorded. Immediately after the slaughter, a cross section from the mid-belly region of the longissimus dorsi (LD) muscle was taken on a paper. A muscle cross-sectional area was then determined by a direct grid reading and fat thickness over the LD muscle, loin thickness and loin to fat ratio were measured by digital caliper (Titan 23175, Titan Electronic Systems, Manchester, UK). Carcasses were chilled for $24 \mathrm{~h}$ at $4{ }^{\circ} \mathrm{C}$ and reweighed to determine the cold carcass weight.

The meat samples from LD and ST muscles were excised out of the right site of the carcasses after slaughter for physical and chemical analyses. Raw meat samples were analysed by AOAC (1990) procedures for dry matter, protein and ash. The intramuscular fat content was measured with the hot extraction method by Ankom extractor (Model XT10, Ankom Technology, Madrid, Spain) in petroleum ether refluxing for $80 \mathrm{~min}$. The protein, ash and intramuscular fat content were determined as a percentage of dry weight.

Meat quality parameters, such as $\mathrm{pH}, \mathrm{CIELab}$, drip loss, cooking loss and share force were analysed as described by Sen et al. (2011). Meat colour characteristics and pH were measured at 1 and $24 \mathrm{~h}$ post-mortem. Observations for meat colour at $24 \mathrm{~h}$ were collected after a $30 \mathrm{~min}$ blooming at the room temperature. Drip loss values of meat samples were calculated on third and seventh day post-mortem. Cooking loss was calculated as a percent difference between the pre-cooked and cooked weights. Shear forces, based on penetrometer readings, values of cooked samples (cut parallel to the muscle fibres with a cross section of $2 \times 2 \mathrm{~cm}$ ) were determined using a Zwick texture meter (Model Z005, Zwick Roell, Ulm, Germany). Mean 
colour characteristics, $\mathrm{pH}$ and shear force data from six measurements of each sample were used in the data analysis.

Individual lambs were considered as experimental units for all data characteristics except for feed consumption. Statistical analyses in terms of feed consumption have not been performed due to the group feeding. Data concerning these characteristics were analysed by ANOVA using GLM procedure of the Minitab 12.11 statistical software (Minitab, Inc., State College, PA, USA) taking into consideration only birth season effect in a mono-factorial model. Significant differences between means were tested by Tukey's multiple comparison tests. Results were computed as mean \pm SE and statistical significance was determined at the level of $P<0.05$.

\section{Results}

Growth performance, some carcass traits, LD muscle characteristics and feed efficiency of the winter born and autumn born Karayaka female singleton lambs are presented in Table 2 .

Table 2

Growth performance, some carcass traits, LD muscle characteristics (means \pm SE) and feed efficiency of the winter and autumn born Karayaka female singleton lambs

\begin{tabular}{lcc}
\hline Traits & Winter born lambs, $\mathrm{n}=15$ & Autumn born lambs, $\mathrm{n}=15$ \\
\hline Growth performance & & \\
Birth weight, $\mathrm{kg}$ & $3.9 \pm 0.2$ & $3.6 \pm 0.3$ \\
Weaning weight, $\mathrm{kg}$ & $18.2 \pm 0.7^{\mathrm{b}}$ & $21.7 \pm 0.7^{\mathrm{a}}$ \\
Slaughter weight, $\mathrm{kg}$ & $30.2 \pm 1.0$ & $31.1 \pm 0.8$ \\
ADG from birth to weaning, $\mathrm{g}$ & $159.1 \pm 6.1^{\mathrm{b}}$ & $201.1 \pm 8.2^{\mathrm{a}}$ \\
ADG from weaning to slaughter, $\mathrm{g}$ & $200.8 \pm 9.1^{\mathrm{a}}$ & $158.2 \pm 13.0^{\mathrm{b}}$ \\
Carcass weight, $\mathrm{kg}$ & & \\
Hot & $14.1 \pm 0.5$ & $13.9 \pm 0.4$ \\
Cold & $13.4 \pm 0.6$ & $13.2 \pm 0.4$ \\
Chilling loss & $0.7 \pm 0.1$ & $0.8 \pm 0.1$ \\
Carcass yield, \% & & \\
Hot & $46.6 \pm 0.6^{\mathrm{a}}$ & $44.9 \pm 0.6^{\mathrm{b}}$ \\
Cold & $44.5 \pm 0.8^{\mathrm{a}}$ & $42.1 \pm 0.6^{\mathrm{b}}$ \\
LD muscle characteristics & & \\
Fat thickness, mm & $3.4 \pm 0.2^{\mathrm{b}}$ & $4.6 \pm 0.3^{\mathrm{a}}$ \\
Loin thickness, mm & $20.4 \pm 0.8$ & $21.6 \pm 0.7$ \\
Loin to fat ratio & $6.1 \pm 0.3^{\mathrm{a}}$ & $4.7 \pm 0.3^{\mathrm{b}}$ \\
Loin area, mm & & $130.1 \pm 2.6$ \\
Feed efficiency, per kg gain & & \\
Consumed concentrate feed & $129.8 \pm 8.2$ & 7.6 \\
Consumed roughage feed & & 0.8 \\
Overall feed efficiency & 6.5 & 8.4 \\
Feed conversion efficiency & 1.0 & 0.12 \\
\hline
\end{tabular}

a,b Means in rows with different superscripts are significantly different at $P<0.05$, 'Statistical analyses between both groups in terms of feed consumption have not been performed due to group feeding

The birth weight and slaughter weight of the winter born lambs and the autumn born lambs were similar, but the weaning weight of the autumn born lambs was higher $(P<0.05)$ than that of the winter born lambs. They also had a higher average daily gain (ADG) up to weaning 
$(P<0.05)$. However, the winter born lambs had a higher ADG $(P<0.05)$ than the autumn born lambs in the post-weaning period. Although, statistical analyses have not been performed between both groups in terms of individual feed consumption due to the group feeding during the post-weaning period, overall feed intake was $12 \%$ greater in the autumn born lambs than in the winter born lambs. There was no significant difference in the mean loin thickness and loin area of LD muscle between the groups, but the autumn born lambs had a higher fat thickness of LD muscle than the winter born lambs $(P<0.05)$. Loin to fat ratio in autumn born lambs were lower than in the winter born lambs $(P<0.05)$. The winter born lambs had a higher average hot carcass and cold carcass yields $(P<0.05)$ but there were no significant differences between the groups in terms of hot carcass weights, cold carcass weights and chilling loss.

Relative weights of non-carcass parts, some organs and muscles of the winter born and autumn born Karayaka female singleton lambs are presented in Table 3. There were no significant differences between lambs born in the winter and autumn seasons in terms of weights of the head, pelt, four legs and pelvic fat. Absolute and relative weights of empty small intestine, empty reticulo-rumen, internal fat, suprarenal fat, total fat, liver and kidney in the autumn born lambs were heavier $(P<0.05)$ but weights of lungs and spleen were lighter $(P<0.05)$ than in the winter born lambs. The heart weight of the autumn born lambs tended to be higher than that of the winter born lambs $(P=0.09)$. The winter born lambs had also heavier GN muscle weights $(P<0.05)$ than autumn born lambs. There were no significant differences between lambs in both groups in terms of ST and SM muscle weights.

Instrumental meat quality characteristics of the winter born and autumn born Karayaka female singleton lambs are presented in Tables 4 and 5 . There were no significant differences between lambs in both groups in terms of $\mathrm{pH}$ values and post-mortem $\mathrm{pH}$ decline in LD and ST muscles. The winter born lambs had a higher drip loss at day 3 and 7 of storage, cooking loss and higher shear force values in LD and ST muscles than the autumn born lambs $(P<0.05)$. Meat lightness $\left(L^{*}\right)$ at $1 \mathrm{~h}$ and $24 \mathrm{~h}$ post-mortem was significantly higher in the winter born lambs $(P<0.05)$ than in the autumn born lambs while their chroma $\left(C^{*}\right)$ values at $24 \mathrm{~h}$ post-mortem, colour difference $(\Delta \mathrm{D})$ and redness $\left(\mathrm{a}^{*}\right)$ at $1 \mathrm{~h}$ and $24 \mathrm{~h}$ postmortem were comparatively lower $(P<0.05)$. The hue angle $\left(H^{\circ}\right)$ values and yellowness $\left(b^{*}\right)$ of ST muscle at $1 \mathrm{~h}$ post-mortem were significantly lower in the autumn born lambs $(P<0.05)$ than in the winter born lambs, but the $H^{\circ}$ and $b^{*}$ values of $L D$ muscle at $24 \mathrm{~h}$ post mortem were significantly higher in the autumn born lambs $(P<0.05)$ than in the winter born lambs. There was no significant difference between lambs in both groups in terms of $C^{*}$ values of ST muscle at slaughter, $b^{*}$ and $H^{\circ}$ values of the ST muscle at $24 \mathrm{~h}$ post-mortem, $\mathrm{b}^{*}, \mathrm{C}^{*}$ and $\mathrm{H}^{\circ}$ values of the $L D$ muscle at $1 \mathrm{~h}$ post-mortem.

Chemical compositions of LD and ST muscles from the winter born and autumn born Karayaka female singleton lambs are presented in Table 6 . There were no significant differences between lambs in both groups in terms of total protein and ash content, but the autumn born lambs had a higher dry matter and intramuscular fat content than the winter born lambs $(P<0.05)$. 
Table 3

Relative weights (\%) of non-carcass parts, some organs and muscles (means \pm SE) of the winter and autumn born Karayaka female singleton lambs

\begin{tabular}{lcc}
\hline Traits & Winter born lambs, $\mathrm{n}=15$ & Autumn born lambs, $\mathrm{n}=15$ \\
\hline Non-carcass parts & & \\
Head & $4.81 \pm 0.42$ & $5.02 \pm 0.43$ \\
Pelt & $12.14 \pm 0.91$ & $12.61 \pm 1.43$ \\
Four leg & $2.56 \pm 0.41$ & $2.51 \pm 0.34$ \\
Small intestine & $2.06 \pm 0.10^{\mathrm{b}}$ & $2.35 \pm 0.10^{\mathrm{a}}$ \\
Reticulo-rumen & $2.94 \pm 0.16^{\mathrm{b}}$ & $3.12 \pm 0.14^{\mathrm{a}}$ \\
Internal fat & $1.45 \pm 0.10^{\mathrm{b}}$ & $2.36 \pm 0.24^{\mathrm{a}}$ \\
Pelvic fat & $0.65 \pm 0.12$ & $0.71 \pm 0.10$ \\
Suprarenal fat & $0.34 \pm 0.07^{\mathrm{b}}$ & $0.60 \pm 0.06^{\mathrm{a}}$ \\
Total fat & $2.45 \pm 0.26^{\mathrm{b}}$ & $3.68 \pm 0.34^{\mathrm{a}}$ \\
Organs & & \\
Lung & $1.30 \pm 0.05^{\mathrm{a}}$ & $1.18 \pm 0.04^{\mathrm{b}}$ \\
Liver & $1.95 \pm 0.08^{\mathrm{b}}$ & $2.32 \pm 0.06^{\mathrm{a}}$ \\
Kidney & $0.29 \pm 0.02^{\mathrm{b}}$ & $0.35 \pm 0.01^{\mathrm{a}}$ \\
Heart & $0.43 \pm 0.01$ & $0.42 \pm 0.01$ \\
Spleen & $0.21 \pm 0.01^{\mathrm{a}}$ & $0.18 \pm 0.01^{\mathrm{b}}$ \\
Muscles & & \\
ST & $0.60 \pm 0.03$ & $0.53 \pm 0.01$ \\
SM & $0.15 \pm 0.06$ & $0.14 \pm 0.04$ \\
GN & $0.32 \pm 0.02^{\mathrm{a}}$ & $0.23 \pm 0.01^{\mathrm{b}}$ \\
\hline
\end{tabular}

a,bMeans in rows with different superscripts are significantly different at $P<0.05$.

Table 4

The $\mathrm{pH}$, drip loss, cooking loss and shear force values (means \pm SE) of LD and ST muscles of the winter and autumn born Karayaka female singleton lambs

\begin{tabular}{|c|c|c|c|}
\hline Traits & Muscle & Winter born lambs, $n=15$ & Autumn born Lambs, $\mathrm{n}=15$ \\
\hline \multicolumn{4}{|l|}{$\mathrm{pH}$} \\
\hline \multirow[t]{2}{*}{$1 \mathrm{~h}$} & LD & $6.49 \pm 0.04$ & $6.51 \pm 0.04$ \\
\hline & ST & $6.64 \pm 0.06$ & $6.54 \pm 0.05$ \\
\hline \multirow[t]{2}{*}{$24 \mathrm{~h}$} & LD & $5.61 \pm 0.02$ & $5.50 \pm 0.03$ \\
\hline & ST & $5.60 \pm 0.02$ & $5.51 \pm 0.02$ \\
\hline \multirow[t]{2}{*}{ pH decline } & LD & $1.10 \pm 0.01$ & $1.09 \pm 0.06$ \\
\hline & ST & $1.03 \pm 0.01$ & $1.01 \pm 0.05$ \\
\hline \multicolumn{4}{|l|}{ Drip loss, \% } \\
\hline \multirow[t]{2}{*}{ Day 3} & LD & $9.12 \pm 0.45^{\mathrm{a}}$ & $4.83 \pm 0.18^{b}$ \\
\hline & ST & $10.29 \pm 0.62^{\mathrm{a}}$ & $6.96 \pm 0.53^{b}$ \\
\hline \multirow[t]{2}{*}{ Day 7} & LD & $12.22 \pm 0.78^{\mathrm{a}}$ & $6.13 \pm 0.67^{b}$ \\
\hline & ST & $14.23 \pm 0.81^{\mathrm{a}}$ & $8.53 \pm 0.72^{b}$ \\
\hline \multirow[t]{2}{*}{ Cooking loss, $\%$} & LD & $24.16 \pm 0.85^{a}$ & $21.75 \pm 0.87^{b}$ \\
\hline & ST & $23.21 \pm 0.71^{\mathrm{a}}$ & $21.13 \pm 0.75^{b}$ \\
\hline \multirow[t]{2}{*}{ Shear force, kg/cm² } & LD & $3.65 \pm 0.16^{a}$ & $2.61 \pm 0.08^{b}$ \\
\hline & ST & $5.45 \pm 0.21^{\mathrm{a}}$ & $3.68 \pm 0.15^{b}$ \\
\hline
\end{tabular}

${ }_{a, b}$ Means in rows with different superscripts are significantly different at $P<0.05$. 
Table 5

Colour characteristics (means \pm SE) of LD and ST muscles of the winter and autumn born Karayaka female singleton lambs

\begin{tabular}{|c|c|c|c|}
\hline Traits & Muscle & Winter born Lambs, $\mathrm{n}=15$ & Autumn born Lambs, $\mathrm{n}=15$ \\
\hline \multicolumn{4}{|l|}{ Lightness } \\
\hline \multirow{2}{*}{$1 \mathrm{~h}$} & LD & $31.78 \pm 0.53^{b}$ & $35.11 \pm 0.42^{\mathrm{a}}$ \\
\hline & ST & $32.02 \pm 0.92^{\mathrm{b}}$ & $39.27 \pm 0.76^{\mathrm{a}}$ \\
\hline \multirow[t]{2}{*}{$24 \mathrm{~h}$} & LD & $34.58 \pm 0.73^{b}$ & $40.53 \pm 0.92^{\mathrm{a}}$ \\
\hline & ST & $38.21 \pm 0.49^{b}$ & $40.84 \pm 0.50^{\mathrm{a}}$ \\
\hline \multicolumn{4}{|l|}{ Redness } \\
\hline \multirow[t]{2}{*}{$1 \mathrm{~h}$} & LD & $20.38 \pm 0.24^{\mathrm{a}}$ & $18.03 \pm 0.23^{b}$ \\
\hline & ST & $22.81 \pm 0.32^{\mathrm{a}}$ & $19.64 \pm 0.30^{\mathrm{b}}$ \\
\hline \multirow[t]{2}{*}{$24 \mathrm{~h}$} & LD & $21.78 \pm 0.31^{\mathrm{a}}$ & $19.04 \pm 0.20^{\mathrm{b}}$ \\
\hline & ST & $22.01 \pm 0.29^{a}$ & $19.68 \pm 0.27^{b}$ \\
\hline \multicolumn{4}{|l|}{ Yellowness } \\
\hline \multirow[t]{2}{*}{$1 \mathrm{~h}$} & LD & $4.81 \pm 0.15$ & $4.64 \pm 0.16$ \\
\hline & ST & $4.98 \pm 0.21^{b}$ & $6.41 \pm 0.19^{a}$ \\
\hline \multirow[t]{2}{*}{$24 \mathrm{~h}$} & LD & $6.23 \pm 0.31^{\mathrm{a}}$ & $4.67 \pm 0.22^{b}$ \\
\hline & ST & $6.72 \pm 0.21$ & $6.91 \pm 0.17$ \\
\hline \multicolumn{4}{|l|}{ Chroma value } \\
\hline \multirow[t]{2}{*}{$1 \mathrm{~h}$} & LD & $19.38 \pm 0.31$ & $18.71 \pm 0.28$ \\
\hline & ST & $20.42 \pm 0.27$ & $20.78 \pm 0.35$ \\
\hline \multirow[t]{2}{*}{$24 \mathrm{~h}$} & LD & $21.83 \pm 0.30^{\mathrm{a}}$ & $19.21 \pm 0.27^{\mathrm{b}}$ \\
\hline & ST & $22.09 \pm 0.29^{\mathrm{a}}$ & $20.84 \pm 0.31^{b}$ \\
\hline \multicolumn{4}{|l|}{ Hue angle } \\
\hline \multirow[t]{2}{*}{$1 \mathrm{~h}$} & LD & $13.75 \pm 0.28$ & $14.18 \pm 0.26$ \\
\hline & ST & $14.08 \pm 0.43^{b}$ & $18.02 \pm 0.56^{\mathrm{a}}$ \\
\hline \multirow[t]{2}{*}{$24 \mathrm{~h}$} & LD & $16.58 \pm 0.63^{\mathrm{a}}$ & $14.04 \pm 0.54^{b}$ \\
\hline & ST & $18.21 \pm 0.27$ & $18.18 \pm 0.28$ \\
\hline \multirow[t]{2}{*}{ Colour difference } & LD & $5.81 \pm 0.63^{\mathrm{a}}$ & $3.48 \pm 0.45^{\mathrm{b}}$ \\
\hline & ST & $6.38 \pm 0.87^{\mathrm{a}}$ & $2.61 \pm 0.32^{b}$ \\
\hline
\end{tabular}

a,b Means in rows with different superscripts are significantly different at $P<0.05$.

Table 6

Chemical compositions (means \pm SE) of LD and ST muscle of the winter and autumn born Karayaka female singleton lambs

\begin{tabular}{lccc}
\hline Traits & Muscle & Winter born, Lambs, $\mathrm{n}=15$ & Autumn born, Lambs, $\mathrm{n}=15$ \\
\hline Dry matter & LD & $25.46 \pm 0.36^{\mathrm{b}}$ & $26.91 \pm 0.42^{\mathrm{a}}$ \\
& ST & $24.61 \pm 0.21^{\mathrm{b}}$ & $25.83 \pm 0.23^{\mathrm{a}}$ \\
Ash & LD & $1.06 \pm 0.01$ & $1.07 \pm 0.01$ \\
& ST & $1.18 \pm 0.03$ & $1.14 \pm 0.04$ \\
Protein & LD & $19.44 \pm 0.41$ & $19.75 \pm 0.36$ \\
& ST & $19.62 \pm 0.39$ & $19.68 \pm 0.33$ \\
Intramuscular fat & LD & $3.65 \pm 0.31^{\mathrm{b}}$ & $4.59 \pm 0.29^{\mathrm{a}}$ \\
& ST & $2.56 \pm 0.18^{\mathrm{b}}$ & $3.21 \pm 0.20^{\mathrm{a}}$ \\
\hline
\end{tabular}

${ }^{a, b}$ Means in rows with different superscripts are significantly different at $P<0.05$. 


\section{Discussion}

The results presented in the current study demonstrate that Karayaka female lambs born in the winter and autumn seasons had different growth patterns at weaning and post-weaning, despite the fact that they had similar birth weights. The data also confirm that carcass compositions and some meat quality traits of female lambs were influenced by different lambing seasons.

The birth weight is one of the most important factors influencing pre-weaning growth in lambs, since lambs that are heavier at birth grow faster than lightweight ones and lambs born in different seasons of the year tend to have different birth weights (Susic et al. 2005). Yilmaz et al. (2007) reported that the winter born lambs are heavier at birth and weaning than both the autumn and the summer born lambs while Susic et al. (2005) reported that the spring born lambs are heavier at birth and weaning than the autumn or winter born lambs. In the present study the winter and the autumn born lambs had similar birth weights.

Yilmaz et al. (2007) reported that the lambing in the winter season gave rise to heavier lambs at weaning, but the autumn born lambs were $19.3 \%$ heavier at weaning than the winter born lambs in the present study. The seasonal differences in weaning weight and lamb growth rate up to the weaning in the present study may partly be due to weather conditions which directly affect herbage quantity and quality of the pasture. The winter months have relatively poor quality pasture than the autumn months in the region where the study was carried out due to a low rate of rain fall (Figure 1). Therefore nutrient intake of ewes may be inadequate for lactation and this could affect milk production of the dam. As a result of this, lambs may not be adequately fed resulting in a decline in their growth. The amount and composition of the dam's milk may influence the performance of lambs during the pre-weaning period which may in turn affect growth performance of lambs following weaning. Unfortunately observations regarding to the milk yield and composition were not recorded in the present study which may help to interpret whether these had any effect on the performance of lambs. Although all lambs were fed ad libitum in sheepfold and not permitted to pasture in the post weaning period, interestingly the winter born lambs exhibited an increase in growth rates despite their lower body weights at weaning. The winter born lambs had a higher ADG during post-weaning than the autumn born lambs. Therefore the body weight differences between the winter and autumn born lambs at weaning were not evident at the slaughter age of day 150 . Additionally, characteristics of dams may have an influence on the performance of lambs. However, there were no differences between dams of lambs in both groups in term of age, parity and live weight at mating in the present study (data not shown).

The average carcass weights of all female lambs were consistent with the weights usually achieved by the Karayaka breed slaughtered at similar age (Sen et al. 2011). In the present study, the lambs in both groups had a similar body weight and carcass weight at slaughter age, but the autumn born lambs had a higher proportion of fat (internal and suprarenal fat) in the carcass and they had a lower loin to fat ratio when compared to lambs born in the winter. This situation may be a result of high feed intake because lambs born in the autumn were subjected to lower temperatures in the post-weaning period compared to the post-weaning period of lambs born in the winter since lower environmental temperature increases the feed intake as observed in the present study. These findings are in agreement with the argument 
of Cam et al. (2007) who observed significant effects of lower temperatures on feed intake in sheep. The proportion of fat in the carcass and non-carcass increases as lambs grow (Lefaucheur 2006). Perhaps, the reason for a higher fat deposition in the autumn born lambs may be environmental conditions such as photoperiod, which regulates plasma hormone concentrations related to reproduction and growth in sheep (Chemineau et al. 2008). Although the body weights of lambs in both groups were similar at slaughter age, the empty small intestine, empty reticulo-rumen, liver, kidney and heart weight of the autumn lambs born were heavier than that of the winter lambs. Thus, the carcass yield showed a decrease in lambs born in the autumn. The differences between the groups in terms of heart, liver, reticulo-rumen and small intestine which are defined as supply organs may be explained by the fact that lambs born in the autumn received the solid feed earlier than those born in the winter due to pasture access (Norouzian et al. 2011).

Lamb meat production has seasonal variations in quantity and quality, which are low in autumn and high in late spring and summer due to the usual lambing season (february and march lambings; Chemineau et al. 2008). The autumn born lambs had a higher content of intramuscular fat in LD and ST muscle than the winter born lambs. Therefore, meat quality traits of the autumn born lambs were altered by intramuscular fat content. Intramuscular fat, pH (Atay et al. 2009) and muscle fibre composition (Lefaucheur 2006, Sirin et al. 2011) affect the meat colour index, which is an important trait of meat quality. Moreover, a large amount of intramuscular fat can increase lightness and can decrease redness values, even if the pigment content is increased (Brzostowski et al. 2006). The increase in $L^{*}$ and decrease in $a^{*}$ parameter of $L D$ and ST muscles of the autumn born lambs in the present study may be due to a higher intramuscular fat content of these muscles.

The chroma, hue angles and colour difference are more closely related to the visual appearance of meat. Young \& West (2001) reported that colour differences and hue angle values are good indicators of discoloration progressed in meat during retail display. These authors also reported that a decrease in the chroma value of meat is seen as dull. In the present study, the lower colour difference and chroma values at $24 \mathrm{~h}$ after slaughter in LD and ST muscles of the autumn born lambs may stem from altered lightness and redness values caused by a high intramuscular fat content.

The water holding capacity (WHC) is an indicator of meat quality at the commercial level. Water is normally held in the myofibrils in the space between filaments and a small portion of this water is bound to proteins by electrostatic attraction (Miranda-de la Lama et al. 2009). The level of the WHC of meat is also closely related to the ultimate meat $\mathrm{pH}$ and rates of $\mathrm{pH}$ decline during the development of rigor mortis (Hopkins et al. 2006, Atay et al. 2009). In the present study, drip loss and cooking loss values were used to determine the WHC of raw and cooked meat, respectively. Drip loss, shear force and $\mathrm{pH}$ values of meat influence meat quality parameters such as intramuscular fat, muscle fibre composition and the amount of stromal tissue (Hopkins et al. 2006, Esenbuga et al. 2009).

Dunshea et al. (2005) showed a decrease in intramuscular fat, an increase in drip loss, shear force and $\mathrm{pH}$ values of meat. In the present study the autumn born lambs had high proportions of fat in the carcass and intramuscular fat content. Therefore they also had a lower drip loss and lower shear force values in ST and LD muscles compared to the winter born lambs, but there was no significant difference between lambs in both groups in terms of $\mathrm{pH}$ values in both muscles. Cooking loss mainly occurs through the release of hydration water 
bound to proteins (Miranda-de la Lama et al. 2009). In the present study the lambs in both groups had similar protein content in spite of a decrease in cooking loss values in the autumn born lambs. The cooking loss also depends on the amount of connective tissue and fat will melt and drip out while cooking (Hopkins et al. 2006). However, more research is required to understand the exact mechanisms that affect the WHC of meat (drip loss, cooking loss).

Different seasons had a significant effect on growth performance, some carcass traits and meat quality of Karayaka female lambs. This may be due to the differences in the availability of feeding resources and climatic conditions. Previously published studies revealed that high fat depositions in body cause defections in the reproduction tract (Robinson et al. 2005, Munoz et al. 2009). The culling of autumn born female lambs is a relevant practice for sheep production systems as they have high fat depositions in their body. Therefore new feeding systems should be developed to obtain lambs with an optimal body fat content, if these autumn born female lambs will be used for breeding. The differences in the growth pattern, body composition, meat quality and the weights of developmentally important organs of the lambs born in different lambing seasons may also be due to the differences between nutritional conditions of these pregnancy seasons as it has been reported that nutritional status of the dams during pregnancy may affect the postnatal growth patterns, organ weights and body compositions (Kuran et al. 2007, Ensoy et al. 2008, Kuran et al. 2008a, 2008b, Sen et al. 2008).

Our results suggest that the winter season gives rise to heavier lambs at post-weaning and lambs born in different seasons have different growth patterns. Autumn lambing can be an alternative lambing system for sheep farmers and growth performances of autumn born lambs can be considered as satisfactory in our study, but they had a higher fat content in the carcass and a higher intramuscular content. This may affect customer preferences for a high fat content of lamb's meat due to health concerns. The data confirm that the influence of different lambing seasons on growth performance, carcass and meat quality which is very important and should be taken into account for breeding purposes in sheep production systems.

\section{Acknowledgements}

The authors are grateful to Dr. N. Ocak for his critical editing of the manuscript. The technical support of Dr. E. Sirin in meat quality analyses is also acknowledged.

\section{References}

AOAC (1990) Official methods of analysis of the Association of Official Analytical Chemists. 15th ed., Washington, USA

Atay O, Gökdal Ö, Eren V, Cetiner S, Yikilmaz H (2009) Effects of dietary vitamin E supplementation on fattening performance, carcass characteristics and meat quality traits of Karya male lambs. Arch Tierz 52, 618-626

Brzostowski H, Niznikowski R, Milewski S (2006) Composition and properties of meat of Pomeranian purebred lambs and their crossbreeds with Berrichon du Cher and Charolaise. Arch Tierz 49, 494-501

Cam MA, Kuran M (2004a) Effects of a single injection of hCG or GnRH agonist on day 12 post mating on fetal growth and reproductive performance of sheep. Anim Reprod Sci 80, 81-90

Cam MA, Kuran M (2004b) Shearing Pregnant Ewes to Improve Lamb Birth Weight Increases Milk Yield of Ewes and Lamb Weaning Weight. Asian-Aust J Anim Sci 17, 1669-1673 
Cam MA, Kuran M, Yildiz S, Selcuk E (2002) Fetal growth and reproductive performance in ewes administered $\mathrm{GnRH}$ agonist on day 12 post- mating. Anim Reprod Sci 72, 73-82

Cam MA, Olfaz M, Garipoglu AV (2007) Shearing male lambs in the cold season improves the carcass yield without affecting fattening performance. Anim Sci J 78, 259-265

Chemineau P, Guillaume D, Migaud M, Thiéry JC, Pellicer-Rubio MT, Malpaux B (2008) Seasonality of Reproduction in Mammals: Intimate Regulatory Mechanisms and Practical Implications. Reprod Dom Anim 43 (Suppl.), 40-47

Dunshea FR, D'Souza DN, Pethick DW, Harper GS, Warner RD (2005) Effects of dietary factors and other metabolic modifiers on quality and nutritional value of meat. Meat Sci 71, 8-38

Ensoy Ü, Aksoy Y, Sirin E, Sen U, Ulutas Z, Kuran M (2008) Growth performance, muscle development, carcass characteristics and meat quality of lambs with varying birth weights. Arch Tierz 51 Special Issue, 35-36

Esenbuga N, Macit M, Karaoglu M, Aksakal V, Aksu MI, Yoruk MA, Gul M (2009) Effect of breed on fattening performance, slaughter and meat quality characteristics of Awassi and Morkaraman lambs. Livest Sci 123, $255-260$

Hopkins DL, Hegarty RS, Walker PJ, Pethick DW (2006) Relationship between animal age, intramuscular fat, cooking loss, pH, shear force and eating quality of aged meat from sheep. Aust J Exp Agr 46, 879-884

Kuran M, Onal AG, Robinson JJ, Mackie K, Speake BK, McEvoy TG (1999) A dietary supplement of calcium soaps of fatty acids enhances luteal function in sheep. Anim Sci 69, 385-393

Kuran M, Sen U, Sirin E and Aksoy Y (2008a) Level of maternal nutrition between day 30 and day 80 of pregnancy affects postnatal muscular development of lamb offspring on day 150. In: Book of Abstracts of 59th Annual Meeting of EAAP 14,155

Kuran M, Sen U, Sirin E, Aksoy Y, Ulutas Z (2008b) The effect of maternal feed intake during the peri-conception period on myogenesis in fetal sheep. Arch Tierz 51 Special Issue, 18

Kuran M, Sen U, Sirin E, Aksoy Y, Kilinc K and Ulutas Z (2007) Maternal nutrition from day 30 to day 80 of pregnancy in singleton bearing ewes increases the lamb birth weight. Book of Abstracts of 58th Annual Meeting of EAAP 13, 210

Lefaucheur L (2006) Myofibre typing and its relationships to growth performance and meat quality. Arch Tierz 49 Special Issue, 04-17

Miranda-de la Lama GC, Villarroel M, Olleta JL, Alierta S, Sanudo C, Maria GA (2009) Effect of pre-slaughter logistic chain on meat quality of lambs. Meat Sci 83, 604-609

Munoz C, Carson AF, McCoy MA, Dawson LER, Wylie ARG, Gordon AW (2009) Effects of plane of nutrition of ewes in early and mid-pregnancy on performance of the offspring: Female reproduction and male carcass characteristics. J Anim Sci 87, 3647-3655

Norouzian MA, Valizadeh R, Vahmani P (2011) Rumen development and growth of Balouchi lambs offered alfalfa hay pre- and post-weaning. Trop Anim Health Prod 43, 1169-1174

Ocak N, Cam MA, Kuran M (2006) The influence of pre- and post-mating protein supplementation on reproductive performance in ewes maintained on rangeland. Small Rumin Res 64, 16-21

Olfaz M, Ocak N, Erener G, Cam MA, Garipoglu AV (2005) Growth, carcass and meat characteristics of Karayaka growing rams fed sugar beet pulp, partially substituting for grass hay as forage. Meat Sci 70, 7-14

Olfaz M, Soydan E, Onder H, Ocak N (2010) The Oestrous Behavior of the Karayaka Sheep in Turkey. Asian J Anim Vet Adv 5, 93-102

Robinson JJ, Ashworth CJ, Rooke JA, Mitchell LM, McEvoy TG (2006) Nutrition and fertility in ruminant livestock. Anim Feed Sci Tech 126, 259-276

Sen U, Aksoy Y, Sirin E, Ulutas Z, Kuran M (2008) Pregnancy season affects organ development and fattening performance of ewe lambs. In: Book of Abstracts of 59th Annual Meeting of EAAP 14, 157

Sen U, Sirin E, Ulutas Z, Kuran M (2011) Fattening performance, slaughter, carcass and meat quality traits of Karayaka lambs. Trop Anim Health Prod 43, 409-416 
Sirin E, Aksoy Y, Sen U, Ulutas Z, Kuran M (2011) [Effect of Lamb Birth Weight on Fiber Number and Type of Semitendinosus Muscle]. Anadolu J Agric Sci 26, 63-67 [in Turkish]

Susic V, Pavic V, Mioc B, Stokovic I, Ekert Kabalin A (2005) Seasonal variations in lamb birth weight and mortality. Vet Arhiv 75, 375-381

Ulutas Z, Sezer M, Aksoy Y, Sirin E, Sen U, Kuran M, Akbas Y (2010) The Effect of Birth Types on Growth Curve Parameters of Karayaka Lamb. J Anim Vet Adv 9, 1384-1388

Unal N, Akcapinar H, Atasoy F, Aytac M (2006) Some reproductive and growth traits of crossbred genotypes produced by crossing local sheep breeds of Kivircik $\times$ White Karaman and Chios $\times$ White Karaman in steppe conditions. Arch Tierz 49, 55-63

Yakan A, Ünal N (2010) Meat production traits of a new sheep breed called Bafra in Turkey 1. Fattening, slaughter, and carcass characteristics of lambs. Trop Anim Health Prod 42, 751-759

Yilmaz O, Denk H, Bayram D (2007) Effects of lambing season, sex and birth type on growth performance in Norduz lambs. Small Rumin Res 68, 336-339

Young O, West J (2001) Meat color. In: Hui YH, Nip WK, Roger RW, Young OA (eds.) Meat Science and Applications. Marcel Dekker, Inc., New York, USA, 39-70 